\title{
Southern Fried Family Planning: Reproductive Politics in the South
}

\section{Christine Sixta Rinehart and Laura R. Woliver}

We examine regulations in thirteen Southern states regarding access to legal abortion, procedures for juveniles and minors seeking birth control or abortions, clinic regulations, and the dynamics of public funding of birth control and abortion. Southern state legislatures play an important strategic role in national anti-legal abortion politics. We analyze the paradox of the Southern population utilizing legal abortion and birth control at comparable levels to other regions of the country, while Southern legislatures consistently restrict access to these options. Our paper integrates gender, social class, race, and sexuality into our analysis of this aspect of Southern and national politics.

The quip, "The Nile is not just a river in Egypt," highlights how people deny the evidence and consequences of their actual behavior. Southerners are no exception to this adage, and Southern behaviors belie many regional stereotypes. Sex scandals from the state of South Carolina (e.g., Governor Mark Sanford and Governor Nikki Haley) alone, have provided much late night television comedy fodder to the point where pundits have begun to wonder whether there is something tainting South Carolina's water (Rosen 2010). Although the South is described as the belt buckle of the Bible Belt, that belt is often, in fact, unbuckled (Sixta and Woliver 2009). Sexual behavior is not more or less rampant in the South in comparison to other regions of the United States despite the religious fervor. What is unique about the South are the Southern legislatures that routinely try to regulate sexual conduct even when their actions are clearly at odds with the behaviors of their state populations.

Reproductive political disputes regularly arise and sideswipe many politicians and activists. When Texas Governor Rick Perry campaigned for the 2012 Republican presidential nomination, for example, he was hounded by social conservatives' angst regarding his policy promoting mandatory Human Papilloma Virus (HPV) vaccinations for young girls as a cancer prevention measure. Cervical cancer is the second leading cause of death for women. Many social conservatives believe the vaccination would encourage higher rates of sexual activity in young girls and sparred with Perry over the

CHRISTINE SIXTA RINEHART is an Adjunct Faculty of Political Science and Women's and Gender Studies at the University of South Carolina, Columbia, South Carolina. LAURA R. WOLIVER is a Professor of Political Science and Women's and Gender Studies at the University of South Carolina, Columbia, South Carolina.

The American Review of Politics, Vol. 34, Winter, 2013-2014: 317-335

(C2013 The American Review of Politics 
mandate (Bassett 2011a). Even seemingly benign public health measures by an otherwise staunchly pro-life/anti-choice conservative Texas Republican governor, then, can get embroiled in the no compromise, little nuanced, heightened polarization of American politics, particularly in the domain of sexuality and reproduction. In another example, Missouri Democratic Governor Jay Nixon was overridden by his Republican legislature after he vetoed a bill that would allow employers and insurers to refuse to cover birth control, abortion or sterilization for moral reasons (Bassett 2012). The idea of the "disappearing center" in American politics (Abramowitz 2010) finds much fertile evidence in Southern family planning politics. Extremists on the conservative side of the spectrum dictate state policies. As we will demonstrate, the inside territory of girls' and women's bodies are closely monitored in the South by political leaders otherwise devoted to small government, individual freedom, and private markets.

The South, as we define it in this article, consists of thirteen states: Alabama, Arkansas, Florida, Georgia, Kentucky, Louisiana, Mississippi, Missouri, North Carolina, South Carolina, Tennessee, Texas, and Virginia. The terminology "South" not only refers to a geographic location within the United States but also refers to the states that belonged to the Confederacy during the American Civil War. The Confederate flag represented thirteen states (stars) even though both Kentucky and Missouri were almost evenly spilt concerning allegiance between the Union and the Confederacy. We use the term the "South," then, based on both history and geography. In this analysis, we examine indicators such as abortion statistics, abortion law, counseling and waiting periods, procedures for juveniles and minors seeking birth control, regulations of clinics, and the dynamics of public funding of birth control to reveal the complexities of Southern reproductive behavior and policies.

\section{Southern Families in Context}

Families of all types in the South can often be categorized as beleaguered. The thirteen Southern states have some of the highest poverty rates in the country, the poorest schools, the least funded social support systems, the highest teenage pregnancy rates, the lowest birth weight rates, high domestic violence rates, and high rates of sexually transmitted diseases (STDs) including HIV/AIDS. Part of these problems can be traced to poor economic situations and lack of funding for proper education. Many studies display a strong link between women's levels of education and fertility. A higher level of education correlates with decreased fertility levels and leads to increased economic growth (Klasen and Lamanna 2009). Women who have more education are also likely to have fewer children. Problematically, 
investment in schools, however, is not a strong motif in Southern legislatures. Instead, punitive monitoring and restricting reproductive options characterize Southern family planning.

Southern legislatures also play important strategic roles in national abortion politics. Interest group leaders report that national anti-abortion organizations will often test a new restriction in a Southern state first (Woliver 1999). It is often easier and less expensive to introduce and pass anti-abortion bills in Southern states, since Southern states are often controlled by the Republican Party. Therefore, we can state that Republican legislators are instrumental in passing laws in states legislatures to limit family planning options such as abortion and access to contraception. Southern state governments are often one-party systems, with strong legislatures and weak governors.

In addition, the representation of women in Southern state legislatures and statewide offices is notably scant. Many studies have shown the differences that women in state legislatures, Congress, and statewide and national offices make in agendas, debates and discussions, and ultimately policy making (McDonagh 2009; Johnson et al. 2007; Rosenthal 1998; Swers 2002; Thomas 1994, to name a few). Southern governments, however, are noticeably male-dominated (see State by State Reports; Schunk and Teel 2005). Female representatives pay more attention to family issues, health, and family planning. Additionally, research has documented that states with the most restrictive abortion laws have the least funding and fewest programs providing for the well-being of babies, children, women, and families (Schroedel 2000). The South fits this pattern because it has the most restrictive abortion laws, yet it provides less social assistance in comparison to other states in the United States.

Many states (like Kentucky, Mississippi, and South Carolina) are relatively small states where it is easier for small but determined interests to test new public policies at the state level. Activists also anticipate that if the new restrictions are litigated, Southern courts are more likely to uphold the legislation. If state or federal courts rule the restrictions too burdensome and enjoin injunctions, implementation and prolonged litigation is also part of the long term anti-abortion strategy (Woliver 1999).

\section{Access to Birth Control and Family Planning in the South}

One way that states have tried to limit access to abortion and reproductive options is through laws regulating minors. From a national perspective, the rights that minors have regarding sexual reproductive health have expanded greatly over the past 30 years. All but four states offer contraceptive services to minors. Furthermore, Hawaii, Illinois, New Hampshire, New 
Table 1. Minors' Consent Law in Southern States (as of October 1, 2011)

\begin{tabular}{|c|c|c|c|c|c|c|}
\hline State & $\begin{array}{l}\text { Contra- } \\
\text { ceptive } \\
\text { Services }\end{array}$ & $\begin{array}{c}\text { STI } \\
\text { Services }\end{array}$ & $\begin{array}{l}\text { Prenatal } \\
\text { Care }\end{array}$ & Adoption & $\begin{array}{l}\text { Medical Care } \\
\text { for Minor's } \\
\text { Child }\end{array}$ & $\begin{array}{l}\text { Abortion } \\
\text { Services }\end{array}$ \\
\hline Alabama & All $\dagger$ & Al1* & All & All & All & Parental Consent \\
\hline Arkansas & All & All* & All & & All & Parental Consent \\
\hline Florida & Some & All & All & & All & Parental Notice \\
\hline Georgia & All & All* & All & All & All & Parental Notice \\
\hline Kentucky & All* & All* & All* & $\begin{array}{l}\text { Legal } \\
\text { Counsel }\end{array}$ & All & Parental Consent \\
\hline Louisiana & Some & All* & & $\begin{array}{l}\text { Parental } \\
\text { Consent }\end{array}$ & All & Parental Consent \\
\hline Mississippi & Some & All & All & All & All & Parental Consent \\
\hline Missouri & Some & All* & All* & $\begin{array}{l}\text { Legal } \\
\text { Counsel }\end{array}$ & All & Parental Consent \\
\hline North Carolina & All & All & All & & & Parental Consent \\
\hline South Carolina & $\mathrm{All}^{\circ}$ & $\mathrm{All}^{\circ}$ & $\mathrm{A}_{11}^{\circ}$ & All & All & Parental Consent \\
\hline Tennessee & All & All & All & All & All & Parental Consent \\
\hline Texas & Some & All* & All* & & & $\begin{array}{l}\text { Parental Consent } \\
\text { and Notice }\end{array}$ \\
\hline Virginia & All & All & All & All & All & Parental Consent \\
\hline \multicolumn{7}{|c|}{$\begin{array}{l}\text { Source: Guttmacher Institute, State Policies in Brief, An Overview } \\
\text { uary } 1,2012 \text {. } \\
\text { *Physicians may, but are not required to, inform the minor's parents. } \\
\text { †Applies to minors } 14 \text { and older. } \\
\text { 'Applies to mature minors } 15 \text { and younger and to minors } 16 \text { and older }\end{array}$} \\
\hline
\end{tabular}

Jersey, New York, Oregon, Vermont, and Washington do not require any kind of parental consent for minors seeking abortion. In regard to minors' consent, Southern legislation is actually comparable to legislation passed throughout other areas of the country. Most of the Southern states, as seen in Table 1, provide several services to minors including contraceptive services, Sexually Transmitted Infections (STI) services, prenatal care, adoption, care of the minor's child, and abortion services.

All Southern states require parental consent for a minor to have an abortion. The thirteen Southern states all provide at least some type of contraception and STD (sexually transmitted disease) or STI (sexually transmitted infection) services for minors. This legislation concerning minors is progressive considering that the South is the cradle of the anti-choice/prolife movement. 


\section{Legal Abortion in the South}

The history of abortion law in the South is also much more progressive than one would think. Given the solid conservative hegemony in Southern states currently, it is fascinating to recall that many Southern state legislatures were among the first to modernize or liberalize their contraceptive and abortion laws in the 1960s and early 1970s (Burns 2005). Although abortion was not the central concern of medical professionals during the 1960s and early 1970 s, legislatures deferred to medical doctors on abortion laws especially in the South (Burns 2005, 5). One puzzle is how the quiet, elite movement to liberalize state abortion laws between 1966 and 1973 was particularly uncontroversial in the South (Burns 2005, 151). Women's rights language was not used when liberalizing abortion laws before the Roe decision. A medical legitimization emphasis, permitting medical doctors to be the gatekeepers for legal abortion rather than an appeal to morality or rights helped legal abortion legislation pass. Scholars maintain that there were very few feminist or Catholic groups mobilized to polarize the issue in the South during the 1966-1973 reform period (Burns 2005, 191). Therefore, "reform laws, based on a medical, humanitarian frame, met particular success in the South; alternative frames were particularly lacking" (Burns 2005, 191). State restrictions however have eroded a woman's right to choose legal abortion options since Roe v. Wade (1973), especially in the South. The only states outside the South that do not require a physician to perform an abortion are Arizona, Kansas, Montana, New Hampshire, New Mexico, New York, Oregon, Vermont, Washington, and West Virginia. Most states do not require a second physician at the abortion and most states have banned lateterm abortion.

Abortion is a common experience for many women within the United States. Half of all pregnancies are unintended in the United States and of these unintended pregnancies, 22 percent end in abortion. Ten percent of women have an abortion by age $20 ; 25$ percent of women have an abortion by age 30 ; and 30 percent of women have an abortion by age 45 (Guttmacher Institute, August 2011b). After the 1973 Roe v. Wade decision, abortion numbers continued to rise until 1990 when they reached an all-time high of 1,608,600 abortions per year. After 1991, abortion numbers declined slowly to around 1.2 million in 2008 (National Right to Life 2011). Although abortion rates in the United States, until a short time ago, were declining, they have recently reached a plateau and have remained around 20 percent (Guttmacher Institute, August 2011b).

Table 2 provides rates of abortion for Southern states. For the most part, Southern states exhibit similar abortion rates as national trends. Since the Roe decision (1973), most Southern states like Alabama, Arkansas, 
Table 2. Abortions by State of Residence, 2007-2009

\begin{tabular}{lcccc}
\hline & $\begin{array}{c}\text { Number of } \\
\text { Abortions, } \\
\text { by State of } \\
\text { Residence 2007 }\end{array}$ & $\begin{array}{c}\text { Percent of } \\
\text { National } \\
\text { Abortions }\end{array}$ & $\begin{array}{c}\text { State } \\
\text { Population }\end{array}$ & $\begin{array}{c}\text { Number of } \\
\text { Abortions Per } \\
1000 \text { Women } \\
\text { Ages 15-44) } \\
\text { State }\end{array}$ \\
\hline Alabama & 11,130 & 0.93 & $4,708,708$ & 12 \\
Arkansas & 5,690 & 0.47 & $2,889,450$ & 9 \\
Florida & 88,600 & 7.36 & $18,537,969$ & 25 \\
Georgia & 33,680 & 2.80 & $9,829,211$ & 17 \\
Kentucky & 6,110 & 0.51 & $4,314,113$ & 5 \\
Louisiana & 12,520 & 1.04 & $4,492,076$ & 7 \\
Mississippi & 7,850 & 0.65 & $2,951,992$ & 5 \\
Missouri & 6,790 & 0.60 & $5,987,580$ & 6 \\
North Carolina & 30,220 & 2.51 & $9,380,884$ & 17 \\
South Carolina & 13,750 & 1.14 & $4,561,242$ & 8 \\
Tennessee & 15,590 & 1.30 & $6,296,254$ & 15 \\
Texas & 80,510 & 6.69 & $24,782,301$ & 16 \\
Virginia & 32,750 & 2.72 & $7,882,590$ & 18 \\
U.S. Total & $1,202,990$ & 100 & $307,006,550$ & \\
Source: Guttmacher Institute, State Data Center, State Facts About Abortion, 2011a; U.S. Census \\
Bureau, The 2012 Statistical Abstract, 2012; and Henry J. Kaiser Family Foundation, 2011. \\
\hline
\end{tabular}

Florida, Kentucky, Mississippi, Missouri, North Carolina, South Carolina, Texas, and Virginia have abortion rates resembling the national declining trends. However, Georgia, Louisiana, and Tennessee have recently displayed increases in abortion rates, unlike the rest of the United States. Florida and Texas had extremely high rates in 2007 in comparison to the other Southern states. This may be because Florida and Texas are some of the most populous states in the South. Conversely, Arkansas, Kentucky, Mississippi, and Missouri have much lower abortion rates than the other Southern states. The reason for disparities between state and national trends is not known although it may be that women are seeking abortions in some states where clinics are more accessible than in their own state (Guttmacher Institute 2011a).

There are many possible reasons why abortion rates have declined in the United States over the last several decades. Some experts maintain that contraception use is more widespread while others state that women are less fertile. Most likely, some decline in abortion rates has also been caused by state restrictions placed on legal abortions. In addition, there has been a drastic reduction in the number of abortion clinics throughout the United States, which provide about 94 percent of all abortions. Medicinal abortions 
or RU 486, "the abortion pill," account for about 17 percent of all abortions. Medicinal abortions rose from 161,000 to 199,000 between 2005 and 2008 (Crary 2011). The morning after pill, an emergency contraception, also decreases abortion rates by preventing unwanted pregnancies.

The recent economic recession may lead to an increase in abortion rates. "Abortion numbers go down when the economy is good and go up when the economy is bad, so the stalling may be a function of a weaker economy," said University of Alabama political science professor Michael New. "If the economy does better, you'll see numbers trending down again" (Crary 2011). It is probable that people are more likely to terminate a pregnancy if an individual or family's source of income has declined or is insecure. Women are more likely to abort a fetus if they are financially unable to care for a child.

In 2011, laws were passed in record numbers limiting access to abortion (HealthNewsDigest.com 2012). The Guttmacher Institute states,

In the first six months of 2011, states enacted 162 new provisions related to reproductive health and rights. Fully $49 \%$ of these new laws seek to restrict access to abortion services, a sharp increase from 2010, when $26 \%$ of new laws restricted abortion. The 80 abortion restrictions enacted this year are more than double the previous record of 34 abortion restrictions enacted in 2005 and more than triple the 23 enacted in 2010. All of these new provisions were enacted in just 19 states (Guttmacher Institute Media Center 2011).

Southern states were disproportionately among the states passing these restrictive policies.

In all of these Southern states, public funding is available for abortion only in cases of rape, incest, or life endangerment of the mother. As can be seen below in Table 3, abortions must be performed by a licensed physician in every Southern state, except Kentucky. These laws were justified by legislators as protecting the health of women and insuring that an abortion is performed by a professional with a medical degree. In addition, states such as Alabama, Kentucky, North Carolina, Missouri, South Carolina and Virginia have enacted laws requiring that abortions around the time of fetal viability are performed in a hospital. Late-term abortions are not allowed. Many states have permanently enjoined laws concerning late-term abortion such as Alabama, Florida, Kentucky, and Missouri. A permanently enjoined law means that the court has told the state to stop performing late-term abortions although no legislation has been passed in these states concerning late-term abortions.

The mandated waiting periods are based on the legislature's hopes that girls and women might change their minds during that period of time. Prochoice activists frame these waiting periods as additional and unnecessary 
Table 3. Abortion Law in Southern States (as of September 1, 2011)

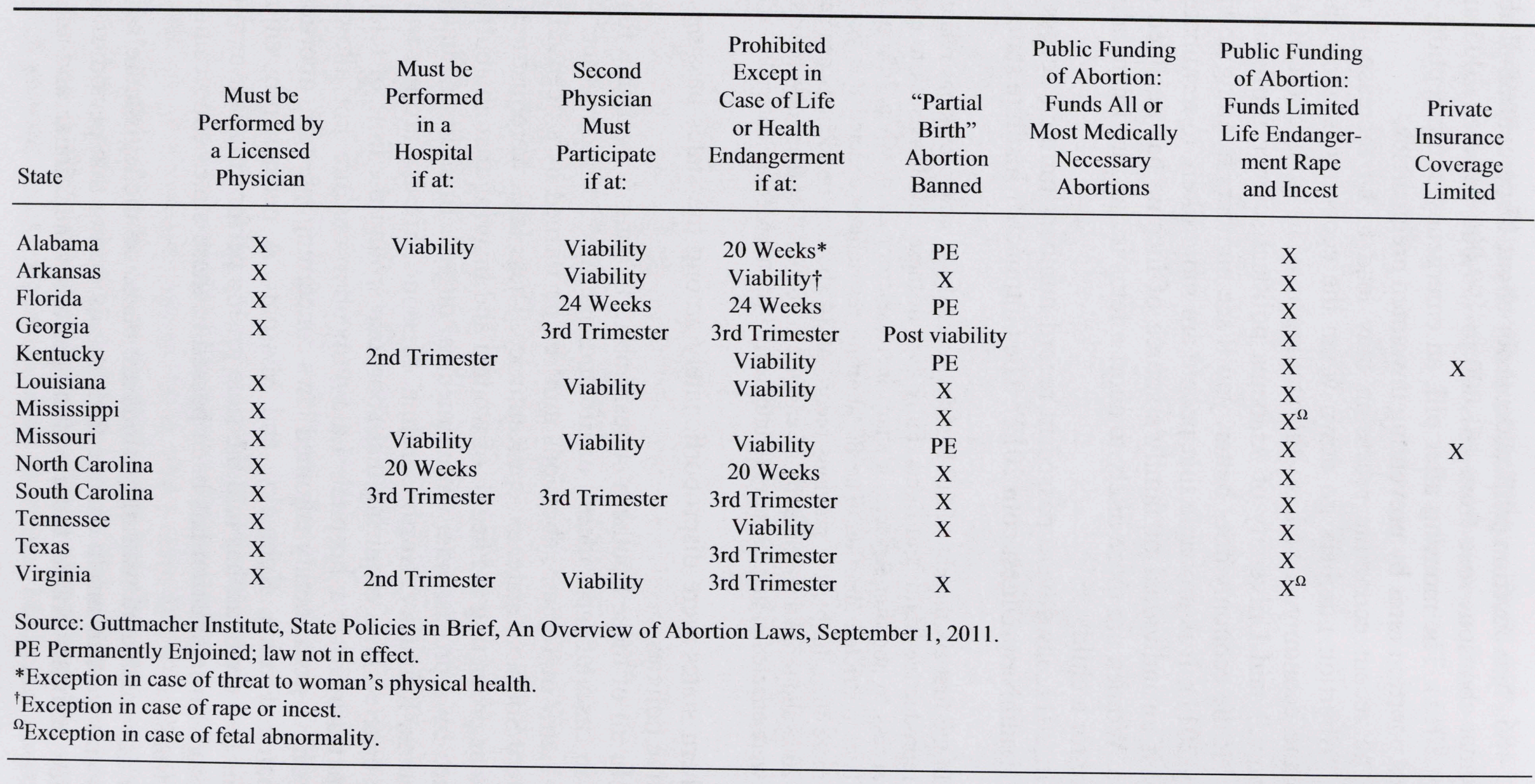


hurdles to clear, making it more expensive and harder for many to access abortion options. According to Table 4, Southern states have done everything within their power to hamper legal abortion. Southern states have increased waiting periods to twenty four hours and many states such as Alabama, Louisiana, and North Carolina require giving women state-approved literature concerning the possible ill effects of abortion. In addition, Arkansas, Georgia, Louisiana, and Texas require that women either be given or offered materials concerning possible pain that the fetus feels during an abortion. Georgia, North Carolina, and South Carolina require that the woman has ultrasound procedures, thus forcing her to see images of the fetus before she has an abortion. All of these measures in Table 4 have been created to encourage women to change their mind about their abortion decision. The waiting periods, mandatory ultrasounds, counseling sessions and materials increase the cost of legal abortions and add to the time patients must spend maneuvering through regulations and mandates. From a national perspective, very few states outside of the South require in-person counseling, which would require two trips to the clinic. Most states do not inform a woman that abortion cannot be coerced. Outside of Southern states, only Indiana, Minnesota, Oklahoma, South Dakota, and Utah give some type of counseling or written materials concerning the ability of a fetus to feel pain.

In addition, targeted regulation of abortion providers laws (TRAP) have been introduced in nineteen states to further restrict access to abortion. Arkansas, Kansas, South Carolina, Utah, and Virginia have enacted these laws. Arkansas requires abortion providers to have a second physician who can handle complications that result from a medication abortion (RU-486). Furthermore, Arkansas requires that second and third trimester abortions are handled in ambulatory surgical centers so abortion providers must meet the same building criteria as ambulatory surgical centers. Virginia recently passed laws concerning the size of operating rooms and widths of hallways within clinics. Many facilities had to have expensive remodeling, such as heating and air conditioning systems reconfigured, further driving up costs and closing some providers. South Carolina passed similar legislation in 1995 that was upheld by the 4th United States Circuit Court of Appeals. South Carolina requires any "facility in which any second trimester or five or more first trimester abortions are performed in a month" to be licensed as an abortion clinic by the Department of Health and Environmental Control (DHEC) (Sluss 2011). In addition, South Carolina's DHEC requires clinics to follow rules concerning sanitation, housekeeping, maintenance, staff qualifications, and emergency equipment. Clinics must also provide many medical items that a hospital provides such as medical records and reports, laboratory equipment, procedure and recovery rooms, physical plants, quality assurance, and infection control. In addition, follow-up care and 
Table 4. Abortion Counseling and Waiting Periods in the South

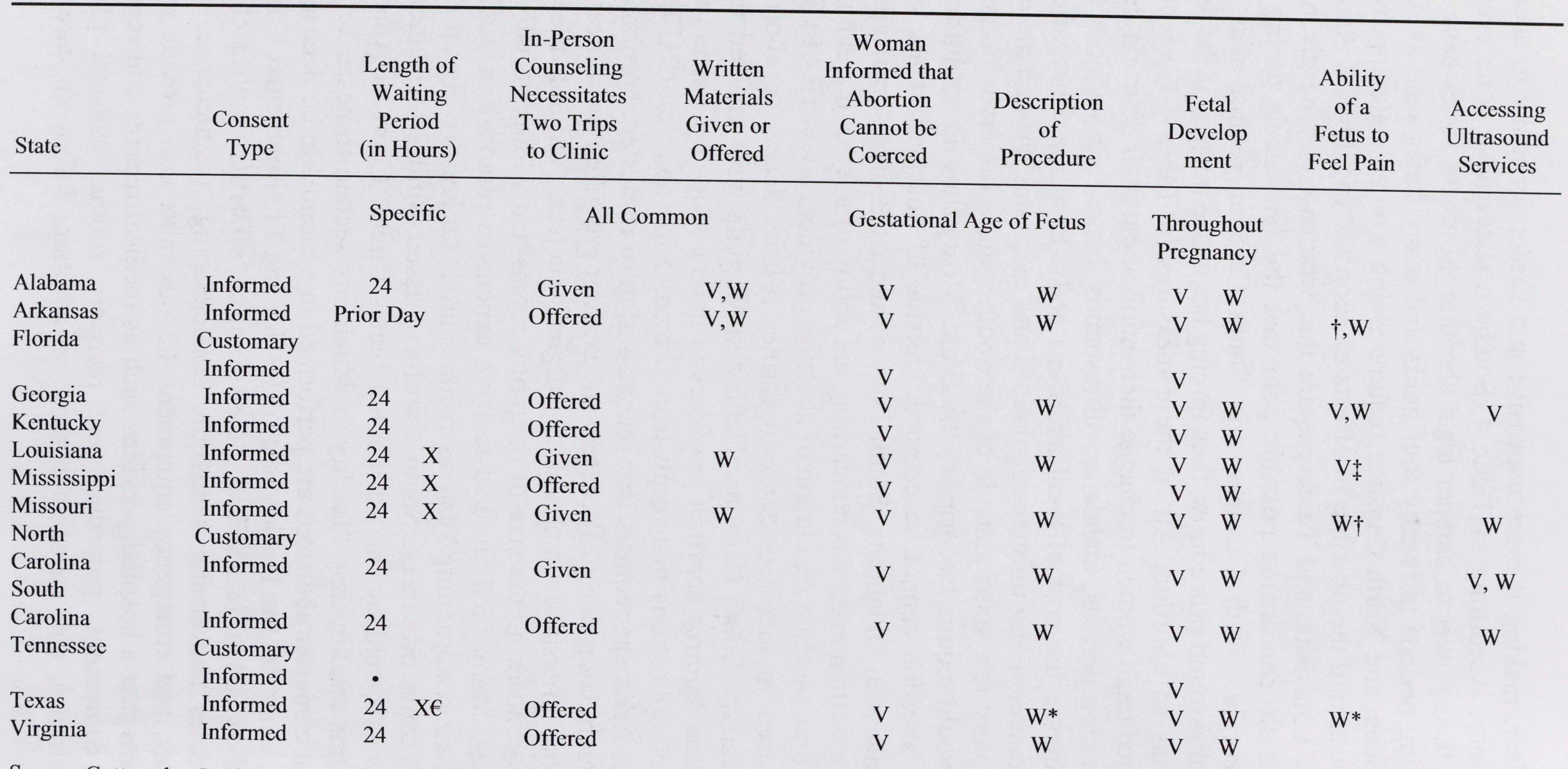

Source: Guttmacher Institute, State Policies in Brief, Counseling and Waiting Periods for Abortion, October 1, 2011 a.

V Verbal counseling. W Written materials. Enforcement permanently enjoined by court order; policy not in *Included in written counseling
materials although not specifically mandated by state law. †Information given only to women who are at 20 weeks' gestation or more; in Missouri the law

applies at 22 weeks gestation. \$The law also requires the information to be included in the written materials; however, the materials have not yet been updated.
$€$ In-person counseling is not required for women who live more than 100 miles from an abortion provider. 
information must also be provided by the abortion clinic (Greenville Women's Clinic v. Bryant 2000).

Eleven of the fifty states have recently introduced legislation that requires abortion clinic doctors to have hospital privileges. Indiana, Kansas, Mississippi, Montana, and Oklahoma have passed this legislation in at least one chamber of their state legislatures. Indiana and Kansas have actually enacted these laws. Mississippi's law would require that any physician who is "associated with" an abortion clinic have admitting and staff rights at a local hospital. This means that the physician must be board certified or eligible to be certified in gynecology or obstetrics (Guttmacher Institute, October 1a, 2011).

Under the guise of caring for women's health, these various abortion laws have drastically lowered the number of abortion clinics in the South and have caused serious problems for the many clinics that are still open. Many proponents of these new laws state that these legal stipulations will make abortion clinics safer, while critics believe that the new laws will force many clinics to go out of business because clinics cannot afford to make these adjustments (Tavernise 2011; Woliver 1999). These regulations will increase the costs for an abortion as clinics cannot make all these changes without incurring greater costs. Legal abortion procedures are already expensive for many women; TRAP policies increase costs. As can be seen in the next section, the number of Southern abortion clinics is decreasing dramatically. TRAP legislation, popular in Southern states, has most certainly played a part in the disappearance of clinics.

\section{A Disappearing Act: Southern Abortion Clinics}

Abortion clinics have continued to close throughout the United States. In 1980, there were approximately 1500 abortion providers nationwide. In 2007, only approximately 600 abortion providers still existed (Guttmacher Institute, August 2011a). Southern states are also closing these clinics in record numbers. Although Southern states have officially continued to allow women to have legal abortions, few clinics exist in these states that can even perform the procedure, as can be seen in Table 5. Access to legal abortion throughout the South has been dramatically diminishing, especially in states like Alabama, Arkansas, Mississippi, South Carolina and Virginia. Arkansas, Mississippi, and South Carolina each have only one clinic. Other states such as Florida, Georgia, Louisiana, North Carolina, Tennessee, and Texas have opened more clinics within the past seven years. Overall, however, the number of abortion clinics has decreased dramatically throughout the South since 1996. 
Table 5. Abortion Clinics in Southern States

\begin{tabular}{|c|c|c|c|c|c|}
\hline State & 1996 & 2000 & 2004 & 2011 & $\begin{array}{c}\text { State } \\
\text { Population } \\
2009\end{array}$ \\
\hline Alabama & 14 & 14 & 5 & 3 & $4,708,708$ \\
\hline Arkansas & 6 & 7 & 2 & 1 & $2,889,450$ \\
\hline Florida & 114 & 108 & 26 & 36 & $18,537,969$ \\
\hline Georgia & 41 & 26 & 5 & 9 & $9,829,211$ \\
\hline Kentucky & 8 & 3 & 2 & 2 & $4,314,113$ \\
\hline Louisiana & 15 & 13 & 2 & 3 & $4,492,076$ \\
\hline Mississippi & 6 & 4 & 2 & 1 & $2,951,992$ \\
\hline Missouri & - & - & - & 4 & $5,987,580$ \\
\hline North Carolina & 59 & 55 & 5 & 9 & $9,380,884$ \\
\hline South Carolina & 14 & 10 & 3 & 1 & $4,561,242$ \\
\hline Tennessee & 20 & 16 & 4 & 6 & $6,296,254$ \\
\hline Texas & 64 & 65 & 22 & 28 & $24,782,301$ \\
\hline Virginia & 57 & 46 & 8 & 5 & $7,882,590$ \\
\hline
\end{tabular}

Source: Abortion Clinics Online 2011.

Note: As this article is a continuation of research, Missouri was not included in our original analysis. Therefore, we have no historical data concerning this state.

Abortion has become a convoluted and highly political procedure (see, for example, HealthNewsDigest.com 2012) in the South. In order to secure access to a legal abortion, women must travel long distances often requiring that they take time off work, have the funds to travel, and provide care for existing children (Guttmacher Institute 2011b). In addition to the expense of the procedure itself, mandatory counseling, twenty-four hour waiting periods, and other regulations increase the costs of legal abortion for providers and patients. Relying on a significant other or family member for help with expenses, transportation, or other accommodations may be problematic for a woman who might fear the consequences of seeking such assistance. All of the Southern states require in-person counseling except Florida and Tennessee, and several states have 24 hour waiting periods so lodging must be purchased for several days. The effects of the operation may also require that a woman stay a few extra days after the procedure to recover.

\section{Overreaching and Defeat: The Mississippi Personhood Amendment, 2011}

In November 2011, Mississippi voters defeated (58\% opposed to $42 \%$ approval) Proposition \#26, a ballot referendum amending the state Consti- 
tution to define human life as beginning at conception. The proposed amendment made no exceptions for rape, incest, or the health of the girl or woman. Analysts noted the measure would ban some forms of legal birth control, impede reproductive technology options for people, and could lead to investigations of girls and women who experienced miscarriages. The measure was deemed so extreme that many pro-life/anti-choice groups and individuals did not support it.

Mississippi is one of only three Southern states with citizen initiatives. A local citizen advocate with ties to the Colorado group "PersonhoodUSA," without the participation of other established pro-life/anti-choice groups, gathered the necessary signatures to put Proposition \#26 on the Mississippi ballot for November 2011. Pro-life/anti-choice groups were divided on the proposition because of the implications it held for birth control methods, punitive monitoring of women experiencing miscarriages, hobbling new reproductive technology, banning stem cell research statewide, and many infertility options. For example, women diagnosed with ectopic pregnancies typically have to have an abortion, since an ectopic pregnancy endangers the life of the mother. If Proposition \#26 passed, it was uncertain how doctors would be able to treat patients with ectopic pregnancies or similar conditions. Importantly, national pro-life/anti-choice groups were concerned that the extreme, iron clad measure could actually result in a legal setback for their agenda. For these reasons, as well as the overreaching nature of the Proposition, some pro-life/anti-choice activists campaigned against the initiative (Grady 2011).

Pro-choice groups strongly oppossed the Mississippi proposition. The blogosphere lit up, for example, with commentary about the Mississippi Personhood Amendment. Politicususa writer, Adalia Woodbury, for instance, opined that Proposition \#26 was insulting to women and seemingly counter to conservative, small government principles. She asserted: "For all the talk that conservatives do about small government, it is clear they don't mean it. At least they don't mean it when it comes to women and their reproductive health. It is just as clear that Mississippi's so called "personhood" amendment has nothing to do with being pro-life. Rather, it attempts to constitutionally reduce women of child bearing age to second class citizens" (Woodbury 2011). That the measure received 42 percent of the vote despite such opposition speaks to the strength of anti-choice sentiment in Mississippi. The overreaching aspect of the proposition, however, helped defeat it with a 58 percent "No" vote. Political observers realize, of course, personhood amendments will be tried again in places like Mississippi with slightly rewritten clauses. 


\section{Analysis and Conclusion}

The conflict that exists between the limitation of family planning options by Southern state legislatures and the widespread use of contraception and abortion in the South is difficult to explain. One possible explanation is the Republican religious right, which dominates Southern politics. The Republican religious right is pro-life/anti-choice and at times, anti-contraceptive. According to a 2009 Gallup Poll, "About half of Republicans are non-Hispanic whites who are strongly religious, defined as those who attend church about once a week or more frequently. Forty percent of Republicans are whites who attend [church] less frequently" (Newport 2009). Election maps indicate that Southern states are controlled by the Republican Party (270towin 2012). Therefore, we can state that Republican legislators are primarily instrumental in passing laws in state legislatures to limit family planning options such as abortion and access to contraception.

One reason for the effectiveness of this opposition is that the political influence of the Southern Baptist Church is strong in the South. Southern Baptists and conservative evangelicals are powerful forces in Southern legislatures (Hudson 2008; The Pew Forum on Religion and Public Life 2008). To underscore their aversion to widely used birth control and family planning measures, at the 2009 Southern Baptist Convention (Gushee 2008, ch. 2), the conclave resolved:

That we decry the President's decision to increase funding for pro-abortion groups and to reduce funding for abstinence education; and be it further RESOLVED, That we oppose the President's determination to strip pro-life healthcare professionals of their conscience protections, punishing them for refusing to participate in or facilitate abortions and other activities that violate their pro-life convictions (Southern Baptist Convention 2009).

Nuance, compromise or empathy for how many Southern citizens sexually behave, with all the resulting consequences and various reproductive health needs are not evident in such resolutions.

Nevertheless, the implications of decreasing access to safe reproductive choices by Southern legislative policies are dire. Given that the South is the poorest region in the country, lack of access to and financing for Southern women in reference to comprehensive family planning adds further hardships to an already socio-economically fragile and beleaguered population. Even before Roe, women with money and connections could get their unplanned, unwanted pregnancies terminated (Graber 1996; Nelson 2003; Reagan 1997; Solinger 2001). The South was no exception. However abortion restrictions in the South have a huge social class impact given the large numbers of Southern women without money, transportation, or safe options. 
According to the National Women's Law Center, approximately 20 percent of Southern women live in poverty. Mississippi, for example, has 21.6 percent of its women living in poverty, the highest rate in the nation (National Women's Law Center 2010). Restricting legal reproductive options, especially in a region with so many socio-economic problems, will have a harsh impact on many girls and women. As many scholars point out, the history of the illegal abortion era included criminal punishments, medical emergencies, and life threatening situations for mostly poor, immigrant and marginalized girls and women (Graber 1996; Reagan 1997; Solinger 2001, 2005; Woliver 1993). As Southern families, especially girls and women, have fewer legal reproductive options, manifold social and economic problems will be further exacerbated. More unwanted pregnancies lead to increased poverty and a higher strain on social services. The underfunded and overworked social service sectors across this country, but especially in the South, inadequately provide a social safety net for poor and beleaguered families currently. Southern legislative restrictions are also introduced, debated, amended, and voted on within assemblies sporting the lowest representation of women in the country, the very people most directly affected by the changes.

At the same time as restrictions are placed on legal abortions, public funding for birth control and family planning has been questioned and targeted. Organizations such as Planned Parenthood that provide free or reduced cost contraceptives and other health care procedures such as mammograms have been constantly attacked. Restricting the availability of contraceptives while also closing access to legal abortions, leaves girls and women, as one Southern adage puts it, "between a rock and a hard place." The unsuccessful Mississippi Human Personhood Referendum ballot initiative of 2011 shows the complexity of these issues in that state legislatures are often pursuing reproductive solutions that are not acceptable to their state populations. The cost of Southern fried family planning options can be prohibitive and intrusive to their poor and underrepresented populations. Nevertheless, the denial option inoculates many Southern policymakers from the realities of citizens' sexual and reproductive behavior and family planning needs.

\section{REFERENCES}

270towin. 2012. Retrieved from http://www.270towin.com. January 19.

Abortion Clinics Online. 2011. Abortion Clinic.com. Retrieved from http://www.gynpages.com/ACOL/listing.html.

Abramowitz, Alan I. 2010. The Disappearing Center: Engaged Citizens, Polarization, and American Democracy. New Haven and London: Yale University Press. 
Baer, Judith A. 1999. Our Lives Before the Law: Constructing a Feminist Jurisprudence. Princeton, NJ: Princeton University Press.

Bassett, Laura. 2011a. Rick Perry's HPV Vaccine Law Sparks Political Fight That Ignores Health Issues. Huffington Post, September 13. Retrieved from http://www. huffingtonpost.com/2011/09/13/rick-perry-hpv-vaccine n 961159.html.

Bassett, Laura. 2011b. Mississippi "Personhood" Law Could Ban Abortions and Birth Control. Huffington Post, September 12. Retrieved from http://www.huffingtonpost.com/2011/09/12/mississippi-personhood-law-abortions n 959100.html.

Bassett, Laura. 2012. Missouri Legislature Overrides Veto of Birth Control Bill. Huffington Post, September 12. Retrieved from www.huffingtonpost.com/mobileweb/ 2012/09/12missouri-birth-control-veto n 1878712.html.

Blanchard, Dallas A. 1994. The Anti-Abortion Movement and the Rise of the Religious Right: From Polite to Fiery Protest. New York: Twayne Publishers.

Burns, Gene. 2005. The Moral Veto: Framing Contraception, Abortion, and Cultural Pluralism in the United States. New York: Cambridge University Press.

Craig, Barbara Hinkson, and David M. O’Brien. 1993. Abortion and American Politics. Chatham, NJ: Chatham House Publishers.

Crary, David. 2011. U.S. Abortion Rate Stalls After Years of Decline. CNS News, January 11. Retrieved from http://www.cnsnews.com/news/article/us-abortion-ratestalls-after-years-decline.

Critchlow, Donald T. 2005. Phyllis Schlafly and Grassroots Conservatism: A Woman's Crusade. Princeton, NJ: Princeton University Press.

Darby, Joseph A. 2011. Nation Following SC Into Abyss. The State Newspaper (Columbia, South Carolina), August 3, p. A7.

DeParle, Jason, Robert Gebeloff, and Sabrina Taverine. 2011. Bleak Portrait of Poverty Is Off the Mark, Experts Say. New York Times, November 4. Retrieved from http://www.nytimes.com/2011/11/04/us/experts-say-bleak-account-of-povertymissed- the-mark.html?pagewanted=all.

Elin, Kathryn, and Laura Lein. 1996. Work, Welfare, and Single Mothers' Economic Survival Strategies. American Sociological Review 61:253-266.

Ford, Lynne E. 2011. Women and Politics: The Pursuit of Equality, 3rd ed. Boston, MA: Wadsworth.

Graber, Mark A. 1996. Rethinking Abortion: Equal Choice, the Constitution, and Reproductive Politics. Princeton, NJ: Princeton University Press.

Grady, Denise. 2011. Medical Nuances Drove 'No' Vote in Mississippi. New York Times, November 15. Retrieved from http://www.nytimes.com/2011/11/15/health/policy/ no-vote-in-mississippi-hinged-on-issues-beyond-abortion.html?pagewanted=all.

Greenville Women's Clinic v. Bryant. 2000. (4th Circuit South Carolina). Retrieved from http://biotech.law.lsu.edu/cases/reproduction/greenville womens clinic.htm.

Gushee, David P. 2008. The Future of Faith in American Politics, the Public Witness of the Evangelical Center. Waco, TX: Baylor University Press.

Guttmacher Institute. 2012, January 1. State Policies in Brief, An Overview of Minors' Consent Law. Retrieved from http://www.guttmacher.org/statecenter/spibs/ spib_OMCL.pdf.

Guttmacher Institute. 2011a, August. An Overview of Abortion in the United States. Retrieved from http://www.guttmacher.org/presentations/abort_slides.pdf.

Guttmacher Institute. 2011b, August. In Brief, Fact Sheet. Retrieved from http://www. guttmacher.org/pubs/fb induced abortion.html. 
Guttmacher Institute. 2011, September 1. State Policies in Brief, An Overview of Abortion Laws. Retrieved from http://www.guttmacher.org/statecenter/spibs/spib OAL. pdf.

Guttmacher Institute. 2011, October 1a. State Policies in Brief, Counseling and Waiting Periods for Abortion. Retrieved from http://www.guttmacher.org/statecenter/spibs /spib_MWPA.pdf.

Guttmacher Institute. 2011, October 1b. State Center. Retrieved from http://www.guttmacher.org/statecenter/updates/index.html.

Guttmacher Institute. 2011a. State Data Center (State Facts About Abortion). Retrieved from http://www.guttmacher.org/datacenter/table.jsp\#.

Guttmacher Institute. 2011b. Abortion. Retrieved from http:/www.guttmacher.org/ sections/abortion.php.

Guttmacher Institute Media Center. 2011, July 13. States Enact Record Number of Abortion Restrictions in First Half of 2011. Retrieved from http:/www.guttmacher. org/media/inthenews/2011/07/13/index.html.

Halva-Neubauer, Glen. 1990. Abortion Policy in the Post-Webster Age. Publius: The Journal of Federalism 20(3):27-44.

HealthNewsDigest.com. 2012. States Enact Record Number of Abortion Restrictions in 2011. January 5. Retrieved from www. HealthNewsDigest.com.

Henry J. Kaiser Family Foundation. 2011. Rate of Legal Abortions per 1,000 Women Aged 15-44 Years by State of Occurrence, 2008. Retrieved from http://www. statehealthfacts.org/comparemapdetail.jsp?ind $=465 \& \mathrm{cat}=10 \& \mathrm{sub}=111 \& \mathrm{kr}=63 \&$ typ $=1 \&$ sort $=\mathrm{a} \& \mathrm{o}=\mathrm{a}$.

Hudson, Deal W. 2008. Onward Christian Soldiers, the Growing Political Power of Catholics and Evangelicals in the United States. New York: Threshold Editions.

Huffington Post. 2011. Obama Administration Revises 'Conscience Clause' Rules: Contraception No Longer Considered Abortion. February 18. Retrieved from http:// www.huffingtonpost.com/2011/02/18/obama-conscience-clause-abortion-contraception n 825461.html.

Johnson, Cathy Marie, Duerst-Lahti, Georgia and Noelle H. Norton. 2007. Creating Gender: The Sexual Politics of Welfare Policy. Boulder, CO: Lynne Rienner.

Klasen, S., and F. Lamana. 2009. The Impact of Gender and Inequality in Education and Employment on Economic Growth: New Evidence from a Panel of Countries. Feminist Economics 15(3):91-132.

Lepore, Jill. 2011. Birthright: What's Next for Planned Parenthood? The New Yorker, November 14, pp. 44-55.

Lepore, Jill. 2009. The Politics of Death: From Abortion to Health Care - How the Hysterical Style Overtook the National Debate. The New Yorker, November 30, pp. 6067.

Luhby, Tami. 2011. Poverty Rate Rises Under Alternative Census Measure. Retrieved from http://money.cnn.com/2011/11/07/news/economy/poverty_rate/index.htm? $\mathrm{hpt}=\mathrm{hp} \mathrm{t2}$.

McDonagh, Eileen. 2009. The Motherless State: Women's Political Leadership and American Democracy. Chicago: University of Chicago Press.

National Right to Life. 2011. Abortion Statistics, United States Data and Trends. September 26. Retrieved from http://www.nrlc.org/Factsheets/FS03 AbortionInTheUS. pdf.

National Women's Law Center. 2010. Poverty Rates by State for 2010. Retrieved from http://www.nwlc.org/sites/default/files/poverty-rates-by-state-for-2010.pdf. 
Nelson, Jennifer. 2003. Women of Color and the Reproductive Rights Movement. New York: New York University Press.

Newport, Frank. 2009. Republican Base Heavily, White, Conservative, Religious. Gallup Poll, June 1. Retrieved from http://www.gallup.com/poll/118937/republican-baseheavily-white-conservative-religious.aspx.

O'Connor, Karen. 1996. No Neutral Ground? Abortion Politics in an Age of Absolutes. Boulder, CO: Westview Press.

The Pew Forum on Religious and Public Life. 2008. U.S. Religious Landscape Survey. Retrieved from http://religions.pewforum.org/pdf/report-religious-landscape-studychapter-1.pdf.

Planned Parenthood. 2011. Morning-After Pill (Emergency Contraception). Retrieved from http://www.plannedparenthood.org/health-topics/emergency-contraceptionmorning-after-pill-4363.asp

Pollitt, Katha. 1995. Fair is Fair: What About Unwed Fathers? The Nation, January 30.

Randolph, Lonnie Jr., and Judith Browne Dianis. 2011. Democracy in Danger. The State (Columbia, South Carolina), November 7, p. A13.

Reagan, Leslie J. 1997. When Abortion was a Crime: Women, Medicine, and Law in the United States, 1867-1973. Berkeley: University of California Press.

Roe vs. Wade. (1973). 410 United States Reports 113.

Rosen, James. 2010. Is it the Water: South Carolina a Magnet for Political Scandal. McLatchey, June 17. Retrieved from http://www.mcclatchydc.com/2010/06/17/ 96110/is-it-the-water-south-carolina.html.

Rosenthal, Cindy Simon. (1998). When Women Lead: Integrative Leadership in State Legislatures. New York: Oxford University Press.

Schneider, Anne, and Helen Ingram. 1993. Social Construction of Target Populations: Implications for Politics and Policy. American Political Science Review 87(2):334347.

Schreiber, Ronnee. 2008. Righting Feminism: Conservative Women and American Politics. Oxford, UK: Oxford University Press.

Schroedel, Jean Reith. 2000. Is the Fetus a Person? A Comparison of Policies Across the Fifty States. Ithaca, NY: Cornell University Press.

Schunk, Donald L., and Saundra J. Teel. 2005. The Status of South Carolina's Women. June. Retrieved from www.allianceforwomen.net.

Segers, Mary C., and Timothy A. Byrnes, eds. 1994. Abortion Politics in American States. Armonk, NY: M.E. Sharpe Publishers.

Sixta, Christine M., and Laura R. Woliver. 2009. Abortion. Pp. 13-17 in The New Encyclopedia of Southern Culture, Vol. 12, Gender, eds. Ted Ownby and Nancy Bercaw. Chapel Hill: University of North Carolina Press.

Sluss, Michael. 2011. Virginia Board of Health Approves Abortion Clinic Regulations. Roanoke Times, September 16. Retrieved from http://www.roanoke.com/politics/ $\mathrm{wb} / 298449$.

Solinger, Rickie. 2001. Beggars and Choosers: How the Politics of Choice Shapes Adoption, Abortion, and Welfare in the United States. New York: Hill and Wang.

Solinger, Rickie. 2005. Pregnancy and Power: A Short History of Reproductive Politics in America. New York: New York University Press.

Southern Baptist Convention. 2009. On President Barack Hussein Obama. Southern Baptist Convention Website, June. Retrieved from http://www.sbc.net/resolutions/ amResolution.asp?ID=1193.

State by State Reports. n.d. Institute for Women's Policy Research. Retrieved from www.iwpr.org/index.cfm. 
State Grades Low on Preterm Births. 2011. The State Newspaper (Columbia, South Carolina), November 16, p. D2.

Stolle, Dietlind, and Elisabeth Gidengil. 2010. What do Women Really Know? A Gendered Analysis of Varieties of Political Knowledge. Perspectives on Politics 8(1): 93-110.

Swers, Michele L. (2002). The Difference Women Make: The Policy Impact of Women in Congress. Chicago: University of Chicago Press.

Symposium: Women's Choices and the Future of Feminism. 2010. Perspectives on Politics 8(1):241-278.

Tavernise, Sabrina. 2011. Virginia Health Board Tightens Rules on Abortion Clinics. New York Times, September 15. Retrieved from http://www.nytimes.com/2011/09/ 16/us/virginia-panel-tightens-abortion-clinic-rules.html.

Thomas, Sue. (1994). How Women Legislate. New York: Oxford University Press.

U.S. Census Bureau. 2012. The 2012 Statistical Abstract: State Rankings. Retrieved from http://www.census.gov/compendia/statab/rankings.html.

Weldon, S. Laurel. 2006. The Structure of Intersectionality: A Comparative Politics of Gender. Politics and Gender 2(2). Symposium on the Comparative Politics of Gender.

Woliver, Laura R. 2003. The Political Geographies of Pregnancy. Urbana: University of Illinois Press.

Woliver, Laura R. 1999. Abortion Conflicts and City Governments: Negotiating Coexistence in South Carolina. Pp. 21-42 in Culture Wars and Local Politics, Elaine B. Sharp, ed. Lawrence: University Press of Kansas.

Woliver, Laura R. 1993. From Outrage to Action: The Politics of Grass-Roots Dissent. Urbana: University of Illinois Press.

Woodbury, Adalia. 2011. What Mississippi's Personhood Amendment Means to Women. Politicususa, November 8. Retrieved from http://www.politicususa.com/en/whatmississippis-personhood-amendment-means-to-women.

Yen, Hope, and Laura Wides-Munoz. 2011. One in Fifteen Among Poorest of the Poor, a Record. The State Newspaper (Columbia, South Carolina), November 3, p. A4. 